\title{
NOTES
}

\section{TAXATION OF INTERCORPORATE ASSET TRANSFERS: AN EXPANDING LOOPHOLE*}

That identical economic results should receive similar tax treatment has long been a basic tenet of the tax system. Yet inconsistency keynotes the tax treatment of intercorporate asset transfers where one corporation acquires the assets of another in exchange for cash or property. ${ }^{1}$

There are three methods of effecting these transactions. ${ }^{2}$

A. Seller corporation may sell the assets directly to Purchaser corporation.

B. Seller corporation may declare a complete or partial liquidation and distribute the assets to its stockholders, ${ }^{3}$ who then sell them to Purchaser corporation. ${ }^{4}$

C. Stockholders of Seller corporation may sell their stock to Purchaser corporation, which then liquidates Seller corporation and takes in the desired assets. ${ }^{5}$

* United States v. Cumberland Public Service Co., 338 U.S. 451 (1950); KimbellDiamond Milling Co., 14 T.C. 74 (1950).

1. This Note will be limited to transactions which entail genuine transfers of interest. It will not deal with those "reorganizations" in which two corporations merge or in which one corporation exchanges its own voting stock for the assets or stock of another corporation. See INT. Rev. Code $\$ \S 112$ (g) (1) (A), (B), (C).

See, generally, Bird, The Purchase of a Corporate Business: Income Taxes, 28 TEXAs L. Rev. 646 (1950); Boley, Income-Tax Problems in the Purchase and Sale of Corporate Assets, 29 ORE. L. Rev. 258 (1950); Magill, Sales of Corporate Stock or Assets, 47 Col. L. Rev. 707 (1947); Notes, 63 HARv. L. REv. 484 (1950), 14 U. of Chr. L. Rev. 647 (1947).

2. The discussion is predicated on several assumptions, generally consistent with present conditions:

1. That the market value of the assets transferred is greater than their tax basis;

2. That the market value of the shareholders' stock in Seller corporation is greater than its tax basis;

3. That Seller corporation shareholders are willing to realize on their appreciated investment; and

4. That Seller corporation stock is held by individuals.

The tax "basis" of property is usually its cost to the taxpayer. INr. REv. CoDE $\$ 113(\mathrm{a})$. But there are numerous exceptions. INT. REv. CODE $\$ 113(a)(1)-(22)$. Gain or loss on the disposition of property is calculated from the "adjusted basis". This takes into consideration factors like depreciation and capital receipts and expenditures. INT. REv. CODE $\$ 113(\mathrm{~b})$.

3. On the taxability of distributions in liquidation, see INT. REv. CODE $\S \S 115(\mathrm{c}),(\mathrm{g})$; U.S. Treas. Reg. 111, $\$ \S 29.115-5,29.115-9$ (1943). INT. REv. CODE $\S 115(i)$ defines "parial liquidation".

4. If the shareholders of a corporation are numerous, the distribution in kind and subsequent sale of the assets may prove unwieldy. These steps can then best be accomplished by appointing a trustee to receive the property and act for the shareholders.

Type $B$ transactions and their tax effects have been extensively discussed in recent legal literature. Probably the best treatment is Cleary, Corporate Distributions in Kind ANd Sale of Property by Stockholders (A.B.A. Practicing Law Institute, 1946).

5. Similarly, Purchaser could buy the stock of Seller corporation and continue to 
Under present law, tax consequences vary with the mode of transfer chosen.

In the present inflationary economy where corporate assets often have a market value greater than depreciated cost, ${ }^{6}$ use of the direct sale type of transaction (type A) usually results in two taxes. Seller corporation is taxed on its gain from the asset sale. ${ }^{7}$ And its stockholders are also taxed. ${ }^{8}$ They must pay either regular income tax if the proceeds are disbursed to them as dividends ${ }^{9}$ or a capital gains tax if they receive the proceeds as a distribution in liquidation. ${ }^{10}$

To avoid this "double tax" stockholders have tried to arrange asset transfers to fall into one of the other categories whenever practicable. When these methods are used only one tax need be paid. Section 29.22(a)-20 of the Income Tax Regulations provides that no taxable gain is realized by a corporation upon the distribution of its assets in kind in complete or partial

operate that corporation as a separate subsidiary. But this would not result in a transfer of assets from Seller to Purchaser. And see note 47 infra.

6. The general price level today stands approximately $90 \%$ above the $1935-39$ average. 30 Survey of Current Business No. 11, S-6 (U.S. Dep't Commerce 1950). Thus a common situation might involve assets purchased in 1935 and depreciated for fifteen years, whose fair market value, because of present high prices, equals or exceeds original dollar cost.

The differential between market value and depreciated cost today is most marked in the case of "emergency facilities" acquired for national defense purposes and amortizable at annual rates as high as $20 \%$. INT. REv. CODE $\$ \$ 124,124 \mathrm{~A}$.

7. INT. REv. CODE § 22(a); U.S. Treas. Reg. 111, § 29.22(a)-18 (1943).

8. We have assumed that Seller corporation's stock is held by individuals. See note 2 supra. The same general principles apply even if the shareholder is a corporation. A corporate stockholder, however, will usually pay smaller taxes because of the credit for dividends received, INT. REV. CODE $\$ 26$ (b) (provided the proceeds are disbursed as a dividend), and because corporate income tax rates do not rise as high as individual rates, INT. REv. CODE $\S \S 13,15$.

9. INT. REv. CODE §§ 22(a), (e), 115(a).

Of course, the distribution will be treated as an ordinary dividend only to the extent that there are earnings or profits of the taxable year or earnings or profits accumulated since March 1, 1913. INT. REv. CODE $\$ \S 115(a),(b)$, (d).

10. Distributions in complete or partial liquidation are regarded as made in exchange for the stock. INT. REv. CoDE $\S 115$ (c). The amount by which the value of the distribution exceeds adjusted basis of stock is taxable at capital gains rates in accordance with INT. REv. CODE $\S 117$ provided the distribution is not essentially equivalent to the distribution of a taxable dividend within the meaning of INT. Rev. CODE $\$ 115(\mathrm{~g})$. This section is most often a threat to partial liquidations but under extreme circumstances may operate as a limitation on complete liquidations as well. See Bittker \& Redlich, Corporate Liquidations and the Income Tax, 5 TAx L. Rev. 437, 455 (1950).

Ordinary income tax rates for individuals rise to a maximum of $87 \%$. INT. REv. CODE $\S 12(\mathrm{f})$. But gains from sale of a capital asset held more than six months are not taxable at rates higher than $25 \%$. INT. REv. CoDE $\$ \$ 117(\mathrm{~b})$,(c). This favorable tax treatment has been subject to much criticism in recent years. See, e.g., Miller, The Capital Asset Concept: A Critique of Capital Gains Taxation, 59 YALE L.J. 837, 1057 (1950).

If, instead of receiving the proceeds as a dividend or a liquidation distribution, the shareholders allow them to remain in the corporation, the value of the corporation will be enhanced. This appreciation will be reflected in the price the shareholders receive when they eventually sell their stock. It will be taxed as a capital gain at that time. 
liquidation. ${ }^{11}$ Thus in the liquidation-asset sale form of transaction (type B) Seller corporation need pay no tax on the liquidation even though its assets have appreciated in value. ${ }^{12}$ The only tax is that paid by its shareholders on the difference between the basis of the stock in their hands and the fair market value of the assets at the time of distribution. ${ }^{13}$ Similarly section 29.22(a)-20 eliminates the tax on asset appreciation in Seller corporation's hands if the stock sale-liquidation device (type C) is used. Only the original shareholders' profits from the stock sale are taxed. ${ }^{14}$

Tax avoidance by the use of these alternative transfer techniques has been inhibited by uncertainty about the exact tax effects of a given transaction. Use of the liquidation-asset sale mode of transfer has been restrained by fear that despite formal conveyance of assets by stockholders the sale would be treated as a direct sale of assets by Seller corporation. ${ }^{15}$ Most of this apprehension was generated by the Supreme Court's opinion in Com-

11. U.S. Treas. Reg. 111, $\$ 29.22$ (a)-20 (1943). An almost identical provision has been in the Regulations ever since Art. 547 of U.S. Treas. Reg. 45 (1919). "Congress, with knowledge of this regulation, has repeatedly revised the income taxing statutes; none of the later acts in any way impinged upon this long standing regulation. This is such direct and convincing proof of legislative approval of the regulation that the courts would not be warranted in overturning it unless it is clearly inconsistent with a statute." First Nat. Bank of Greeley, Colo. v. United States, 86 F.2d 938, 939 (10th Cir. 1936).

The provision has been cited by the Tax Court as decisive in a number of cases. E.g., Ramon Corp., 6 CCH T.C.M. 732 (1947); Lencard Corp., 47 B.T.A. 58 (1942).

12. Where a trustee is used to receive the property for the shareholders, see note 4 supra, care must be exercised that he is not held to be trustee for the corporation and the sale deemed a corporate sale. For in that case additional taxes may be assessed. $C f$. Acampo Winery \& Distilleries Inc., 7 T.C. 629 (1946), acquiesced in, 1949 INT. REv. BuLL. No. 11 at 1 (1949).

13. INT. Rev. CoDE $\$ \$ 111$ (a) and (b), 115(c). If the shareholders sell the assets soon after they receive them in distribution there will be only this one tax. For the basis of the newly received assets in their hands will be the assets' fair market value at the time of distribution. And since it is unlikely that this value will increase over a short period the shareholders will have no gain on the asset sale. However, if the assets do appreciate in the shareholders' hands, there will be an additional tax on the new appreciation when they are sold.

If the liquidation comes under INT. REv. CODE $\$ 112(\mathrm{~b})(7)$, even the shareholders may not have to recognize gain on the liquidation. But under INT. REv. CoDE $\$ 113(\mathrm{a})$ (18) they will then hold the assets at the basis of their stock that was redeemed in the liquidation, decreased by the amount of any money received in the liquidation and increased by the amount of any gain recognized on the liquidation. Thus when the shareholders sell the assets the tax will be imposed on the difference between this basis and the amount received.

14. The selling shareholders will be subject to a capital gains tax on the difference between their basis for the stock and the amount they receive in exchange for it. INT. REv. CODE $\$ 111(\mathrm{a}), 117$.

The price Purchaser corporation pays for the stock will reflect the value of Seller corporation's assets. Therefore Purchaser corporation will have no gain or loss when it liquidates its newly-acquired subsidiary and receives assets for its stock. And, as pointed out, section 29.22(a)-20 prevents any tax on the liquidating corporation.

15. See Cleary, op. cit. supra note 4 , at 38,41 . 
missioner $v$. Court Holding Co. ${ }^{16}$ In that case the corporation itself had negotiated and tentatively consummated an asset sale. Only when the tax consequences were realized was the means of transfer changed. ${ }^{17}$ The Supreme Court upheld the Tax Court's finding ${ }^{18}$ that, although in form there was a liquidation of the corporation followed by a sale of the assets by the shareholders, in substance there was a sale of the assets by the corporation followed by a liquidating distribution of the proceeds to the shareholders. ${ }^{19}$

16. 324 U.S. 331 (1945), reversing, 143 F.2d 823 (5th Cir. 1945), and affirming, 2 T.C. 531 (1943).

17. The corporation's sole asset was an apartment building. All outstanding stock was owned by two people. Negotiations for sale took place between the corporation and the lessees of the building while the corporation still had legal title to the property. An oral sales agreement was reached and a one thousand dollar down payment was made by the lessees. But when the parties met to reduce the agreement to writing, the purchaser was informed that the sale could not be made because of the large corporate tax that would be incurred. The following day the corporation declared a liquidating dividend and the shareholders received the building in exchange for their stock. A contract of sale embodying essentially the terms previously agreed upon was then drawn up between the shareholders as individuals and the same purchaser. The deposit previously made to the corporation was applied against the purchase price. 324 U.S. 331, 332-3 (1945).

18. The Court decision was a strict application of the rule announced in Dobson v. Commissioner, 320 U.S. 489 (1943). The Dobson rule limited the power of appellate courts to review Tax Court decisions. "Whatever latitude exists in resolving questions such as . . treating a series of transactions as one for tax purposes, or treating apparently separate ones as single in their tax consequence, exists in the Tax Court and not in the regular courts; when the court cannot separate the elements of a decision so as to identify a clear-cut mistake of law, the decision of the Tax Court must stand." 320 U.S. 489, 501-2 (1943).

Congress thereafter revised the applicable section of the Code. Pub. L. No. 773, 80th Cong., 2d Sess. (June 25, 1948). Courts of appeals now have the same power to review Tax Court decisions as they have to review decisions of the district courts in civil actions tried without a jury. INT. REv. CODE § 1141 (a).

19. The Court went beyond the language necessary to state that sufficient evidence supported the Tax Court finding. It pointed out: "The incidence of taxation depends on the substance of a transaction. . . . A sale by one person cannot be transformed for tax purposes into a sale by another by using the latter as a conduit through which to pass title. To permit the true nature of a transaction to be disguised by mere formalisms, which exist solely to alter tax liabilities, would seriously impair the effective administration of the tax policies of Congress." 324 U.S. 331, 334 (1945).

Two weeks after the Court decision the Supreme Court denied certiorari in a similar case. There the lower courts had held a corporation taxable on a sale of assets by its partnership successor. "The partnership . . . [was] merely an ingenious method adopted for the sale of the corporate assets." Meurer Steel Barrel Co. v. Commissioner, 144 F.2d 282, 285 (3d Cir. 1944), cert. denied, 324 U.S. 860 (1945).

"It soon became apparent that no workable standard for the guidance of taxpayers, their counsel and government representatives had been established. A variety of techniques was resorted to by taxpayers in an effort to withdraw themselves from the impact of the Court] case. . . " Gutkin \& Beck, Sale of Assets Received on Liquidation, 28 TAxEs 328, 330 (1950). Some of these were successful. E.g., Howell Turpentine Co. v. Commissioner, 162 F.2d 319 (5th Cir. 1947) (negotiations conducted by shareholders to make sale when they received assets in liquidation); Acampo Winery and Distilleries Inc., 7 T.C. 629 (1946) (assets distributed in liquidation and negotiations then conducted by trustees representing shareholders). Others were not. E.g., Kaufmann v. Commissioner, 175 F.2d 28 (3d Cir. 
Use of the stock sale-liquidation device has been checked by section 112(b)(6) of the Internal Revenue Code ${ }^{20}$ and its corresponding basis section, 113(a)(15). ${ }^{21}$ These provisions declare the basis for assets acquired in the liquidation of a subsidiary under certain specified conditions ${ }^{22}$ to be the basis at which those assets were held in the hands of the subsidiary. Thus they apparently require that Purchaser corporation use as its basis for assets obtained in a stock sale-liquidation transaction the basis of the assets in Seller corporation's hands rather than the price paid for the stock. ${ }^{23}$ Under

1949) (president and directors of corporation negotiating for sale by shareholders held to be corporate agents). For a list of recent cases on this subject see 3 P-H 1950 FED. TAX SERV. IT $28,215-16$ (1950).

Following the Court case the liquidation-asset sale device was much discussed. Many commentators suggested precautions which might help avoid the "double tax." But their recommendations were usually tinged with uncertainty. See, e.g., Ayers, Stockholder or Corporate Sale of Assets in Liquidation as Affected by Court Holding Company and Howell Turpentine, New York UnIversity Stxth Annual Institute on Federal Taxation 364, 377-8 (1948).

20. INT. REv. CODE $\$ 112(\mathrm{~b})(6)$. This section provides that no gain or loss shall be recognized when a corporation receives property distributed in the complete liquidation of a subsidiary, provided that certain conditions are satisfied. The parent corporation must own at least 80 per cent of the total combined voting power of all classes of stock entitled to vote, and at least 80 per cent of the total number of shares of all other classes of stock (except non-voting stock which is limited and preferred as to dividends). It may not dispose of any stock between the date of adoption of the plan of liquidation and the time of receipt of the property. The liquidation either must be completed within one taxable year, or a plan of liquidation calling for completion within three years from the close of the taxable year during which the first of a series of liquidation distributions is made must be adopted and carried out.

Section 112(b)(6) was enacted in its present form by the Revenue Act of 1936. 49 Stat. 1648, 1679 (1936). It was designed to facilitate the streamlining of corporate structures by encouraging parent corporations to liquidate subsidiaries. See Busterud, The Liquidation of Subsidiaries under Section 112(b)(6), 58 YALE L.J. 1050 (1949).

21. INT. REv. CoDE $\$ 113(\mathrm{a})(15)$. This section provides that "[i]f the property was received by a corporation upon a distribution in complete liquidation of another corporation within the meaning of section 112 (b) (6), then the basis shall be the same as it would be in the hands of the transferor." This is an exception to the general rule that the basis of property acquired in a tax-free exchange is the same as the basis of the property exchanged. INT. REv. CoDE $\$ 113(\mathrm{a})(6)$.

22. See note 20 supra.

23. The question of the proper basis for assets acquired by a liquidation following closely upon a stock purchase has faced the courts on several occasions. In all these cases the courts found that the intent to acquire the assets themselves was clear from the beginning and held the proper basis for the assets to be the price paid for the stock. Prairie Oil \& Gas Co. v. Motter, 66 F.2d 309 (10th Cir. 1933); Commissioner v. Ashland Oil \& Refining Co., 99 F.2d 588 (6th Cir. 1938), cert. denied, 306 U.S. 661 (1939); Koppers Coal Co., 6 T.C. 1209 (1946); Peoples Water \& Gas Co., 7 CCH T.C.M. 337 (1948). But the transactions involved all antedated the adoption of sections $112(\mathrm{~b})(6)$ and $113(\mathrm{a})(15)$. Considerable speculation arose as to whether this rule applied to transactions subsequent to the adoption of these sections. Some commentators believed that the new provisions did not alter the previous practice. E.g., Stock, Purchase and Sale of a Corporate Business, 27 TAxes 627 (1949). But others asserted that the provisions required an abandonment of the rule. E.g., 
present inflationary conditions the price paid for the stock will generally be much higher than the value of the assets on the books of Seller corporation. ${ }^{24}$ Thus this requirement that a lower basis be used is a strong deterrent to Purchaser corporation's entering into such a transaction. It entails both a lower depreciation allowance and a higher ultimate tax. ${ }^{25}$

Two recent decisions have dispelled some of the doubts about these alternative transfer methods and have made somewhat more evident the means by which the corporate tax may be avoided. United States v. Cumberland Public Service Co. ${ }^{26}$ presents the latest word on the liquidation-asset sale device. The stockholder-officers had negotiated, prior to any liquidation proceedings, to make an asset sale as stockholders. ${ }^{27}$ They did not

Mannix, Liquidation of Newly Acquired Subsidiaries, 26 TAxes 1112 (1948). The arguments -of the latter were fortified by the recommendation of a special tax study subcommittee appointed by Congress. Its report suggested that the law be modified to permit Purchaser corporation to use stock cost as asset basis in those transactions where asset acquisition was its motive. Special Tax Study Committee Report to the Ways and Means Committee, House of Representatives, Majority Report 25 (Nov. 4, 1947). Apparently the subcommittee believed that under present law sections 112(b)(6) and 113(a)(15) would apply.

24. See note 6 supra.

25. "In business, the object is to buy low. For purposes of income tax gain or loss, however, a high basis is doubly advantageous to the taxpayer. It results either in a correspondingly lower taxable gain or a higher deductible loss. Furthermore, it can support a higher deductible depreciation or similar allowance. A low basis is similarly disadvantageous." Moroney \& Colgan, Gain or loss on Sales and Exchanges 44 (A.B.A. Practicing Law Institute, 1946).

Of course buying stock to obtain assets has other disadvantages. Besides the desired assets, Purchaser acquires a going corporation with all the attendant dangers of unknown liabilities and detrimental contracts or commitments. Moreover, the acquired corporation may have a high earned surplus which, under the rule of Commissioner v. Sansome, 60 F.2d 931 (2d Cir. 1932), will carry over to augment any surplus Purchaser may have. Purchaser corporation may then be penalized under INT. REv. CODE $\$ 102$ for maintaining an unnecessarily high earned surplus. And under the stock sale-liquidation device purchaser is also saddled with the additional expenses of liquidation.

But most of these other disadvantages can be guarded against by adequate provisions at the time of stock sale. And complementary advantages such as favorable contracts or pending tax refunds may accrue to the benefit of Purchaser.

To circumvent the low basis requirement of section 113(a)(15), the corporation may try to keep the liquidation from complying with the provisions of section $112(b)(6)$. In a few cases such efforts have been successful. E.g., Commissioner v. Day \& Zimmerman Inc., 151 F.2d 517 (3d Cir. 1945). Contra: Burnside Veneer Co. v. Commissioner, 167 F.2d 214 (6th Cir. 1948). See discussion in Boley, stpra note 1, at 280-1; Friedman, Points to be Considered in Liquidating a Corporation, NEW YORK UNIVERsity FIFTH ANNUAL INSTITUTE ON FEDERAL TAXatTon 747, 788-91 (1947).

26. 338 U.S. 451 (1950), affirming, 83 F. Supp. 843 (Ct. Cl. 1949).

See Notes, 63 Harv. L. Rev. 871 (1950); 19 U. of Cin. L. Rev. 402 (1950).

27. "Details of the transaction are as follows. The respondent, a closely held corporation, was long engaged in the business of generating and distributing electric power in three Kentucky counties. In 1936 a local cooperative began to distribute Tennessee Valley Authority power in the area served by respondent. It soon became obvious that respondent's Diesel-generated power could not compete with TVA power, which respondent had been unable to obtain. Respondent's shareholders, realizing that the corporation must get out 
actually receive the assets in liquidation until some two months after the contract of sale had been completed. ${ }^{28}$ Despite the fact that the tax-avoidance purpose was openly admitted, ${ }^{29}$ the Supreme Court upheld the finding of the Court of Claims that the stockholders had made the sale and refused to impute it to the corporation. ${ }^{30}$ It pointed out that, while a motive to reduce taxes subjects the transfer to most careful scrutiny, it alone cannot cause the transaction to be attributed to the corporation. ${ }^{31}$ Apparently, then, corporate tax may be avoided in the liquidation-asset sale type of transaction as long as there are no negotiations which bind the corporation. ${ }^{32}$ In Kimbell-Diamond Milling Co. ${ }^{33}$ the Tax Court may likewise have

of the power business unless it obtained TVA power, accordingly offered to sell all the corporate stock to the cooperative, which was receiving such power. The cooperative refused to buy the stock, but countered with an offer to buy from the corporation its transmission and distribution equipment. The corporation rejected the offer because it would have been compelled to pay a heavy capital gains tax. At the same time the shareholders, desiring to save payment of the corporate capital gains tax, offered to acquire the transmission and distribution equipment and then sell to the cooperative. The cooperative accepted. The corporation transferred the transmission and distribution systems to its shareholders in partial liquidation. The remaining assets were sold and the corporation dissolved. The shareholders then executed the previously contemplated sale to the cooperative." 338 U.S. 451, 452-3 (1950).

28. The contract was dated June 10,1940. The corporation was dissolved on Aug. 13, 1940. Cumberland Public Service Co. v. United States, 83 F. Supp. 843, 848-9 (Ct. Cl. 1949).

29. Id. at 847,854 .

30. "Here, on the basis of adequate subsidiary findings, the Court of Claims has found that the sale in question was made by the stockholders rather than the corporation. The Government's argument that the shareholders acted as a mere 'conduit' for a sale by respondent corporation must fall before this finding." 338 U.S. 451, 455 (1950).

31. Ibid. The Supreme Court's opinion is reinforced by the discussion during the oral argument of the case. According to an eyewitness account: "When asked by Justice Minton whether the corporation would have dissolved without the existence of the contract to sell, counsel [for the corporation] replied in the affirmative, adding that the taxpayer merely chose the course of least tax resistance. When asked by Justice Reed whether any small corporation would ever shape its transaction in such a way as to require the application of the double tax, counsel responded in the negative and counterquestioned as to whether there was any reason why it should. Justice Reed then replied that he himself would have conducted the transaction along parallel lines." Gutkin \& Beck, supra note 19, at 332.

The genealogy of the aphorism that a taxpayer has the legal right to decrease or avoid his taxes by any means which the law permits extends back to a nineteenth century Supreme Court case-United States v. Isham, 17 Wall. 496 (U.S. 1873). But this policy has been somewhat circumscribed in recent years by the "business purpose" doctrine enunciated in Gregory v. Helvering, 293 U.S. 465 (1935). That doctrine declared that tax avoidance transactions not motivated by business considerations will not be respected. It has been incorporated in part into the. Code. INT. REv. CODE $\$ 129$. Similar limitation of the Isham policy has resulted from the practice of basing tax liabilities on the "reality" of the transaction and not the "mere form" employed in bringing it about. This is exemplified by Commissioner v. Court Holding Co., 324 U.S. 331(1945).

32. See 1 Rabkin \& Johnson, Federal Income, Gift and Estate Taxation 1317 (Rev. ed. 1950).

33. 14 T.C. 74 (1950). The case is now pending in the United States Court of Appeals for the Fif th Circuit. 5 CCH 1950 FEd. TAX. REp. 11,873 (1950). 
opened the door to increased use of the stock sale-liquidation method of transfer. In this case petitioner had bought all the stock of a nearby milling company. In accordance with a resolution of petitioner's board of directors made before the stock acquisition, the new subsidiary was immediately dissolved and its assets distributed to petitioner ${ }^{34}$ In computing its tax returns petitioner relied on sections $112(\mathrm{~b})(6)$ and $113(\mathrm{a})(15)$. It used as the basis of the distributed assets their basis in the subsidiary's hands. Due to special circumstances in the case this was a considerably higher figure than the assets' "cost", ${ }^{35}$ which the Commissioner contended was the proper basis. The Tax Court agreed with the Commissioner. Refusing to recognize the liquidation, it held sections $112(\mathrm{~b})(6)$ and $113(\mathrm{a})(15)$ inapplicable. It pointed out that where the essential nature of a transaction is the acquisition of property, the purchase and subsequent liquidation must be considered as one transaction - the purchase of assets. ${ }^{36}$ At present it is not clear whether the courts will follow this rationale in those stock sale-liquidation cases where the Commissioner asserts the applicability of sections 112(b)(6) and 113(a)(15) and it is the taxpayer who claims the stock cost as asset basis. ${ }^{37}$ If they do, use of this mode of transfer will be greatly facilitated.

34. The resolution provided that Kimbell-Diamond Milling Company should purchase the entire capital stock of the Whaley Mill \& Elevator Company. It stated that, as soon as practicable after the stock purchase, all necessary steps should be taken to liquidate the acquired corporation by transferring its entire assets to Kimbell-Diamond Milling Company in cancellation and redemption of the stock. 14 T.C. 74, 76 (1950).

35. Petitioner's mill property had been destroyed by fire some four months before the stock acquisition. At that time the mill had an adjusted basis of $\$ 18,921$. Petitioner received $\$ 124,551$ in insurance proceeds. It used $\$ 118,200$ of this money plus an additional $\$ 91,799$ to pay for Seller corporation's stock. It did not report as income the difference between the insurance proceeds and the basis of the destroyed property. An earlier Tax Court decision held that this was proper since, as a result of the fire, the mill was involuntarily converted into like property under INT. Rev. CODE $\$ 112$ (f). Kimbell-Diamond Milling Co., 10 T.C. $7(1948)$. But on procedural grounds the court refused to decide at that time whether the stock purchase constituted acquisition of assets. Id. at 14. This issue came up when the Commissioner questioned the basis which petitioner used for the newly-acquired assets in a subsequent tax return.

Under INT. REv. CODE $\$ 113(\mathrm{a})(9)$ the basis for assets acquired in place of assets involuntarily converted is the basis of the assets converted plus the amount of any money expended over and above the amount received as indemnification for those assets. The Commissioner asserted that the purchase of Seller's stock and the subsequent liquidation in order to acquire the mill were tantamount to a purchase of the mill. Therefore under section $113(\mathrm{a})(9)$ the basis of the mill should be the "cost" of $\$ 110,720$ ( $\$ 18,921$ adjusted mill basis plus $\$ 91,799$ expended above insurance proceeds). But petitioner urged that since it had liquidated a subsidiary under section 112(b)(6) its basis should be the adjusted basis of the assets in the subsidiary's hands, a figure of $\$ 139,521$. 14 T.C. 74, 75-9 (1950).

36. 14 T.C. 74,80 (1950). The court quoted as authority the line of decisions cited at note 23 supra.

Little more than a month later the Tax Court cited these same cases plus KimbellDiamond Milling Co. as decisive of the issue in Ruth M. Cullen, 14 T.C. 368, 373 (1950). In that case it was also held that the several steps employed in carrying out a single purpose must be regarded as a single transaction for tax purposes.

37. The courts may be willing to apply a mode of reasoning to a particular set of facts 
In elucidating how the "double tax" may be avoided, the Cumberland and Kimbell-Diamond decisions make more real the problem of corporate tax avoidance in asset transfers ${ }^{38}$ and highlight some of the inequities of our present system. It is now somewhat clearer just when different methods of transferring assets from Seller corporation to Purchaser corporation will have different tax results; but there is no justification for the existence of such differences. The basic policies of our tax system require that equal tax consequences accrue to the same economic result, no matter by what devious means it is reached. ${ }^{39}$ Yet within the existing statutory framework the courts had little choice but to ignore the economic realities as they did. It seems unlikely that present tax doctrines can be judicially extended to equalize treatment of the three transactions. Steps toward amelioration should be taken by Congress.

In its sole recent effort to correct this situation Congress considered imposing uniform treatment by eliminating the corporate tax even when the asset sale was made by Seller corporation. ${ }^{40}$ Such a provision would indeed

when the Commissioner asserts its applicability. It does not necessarily follow that they will apply the same reasoning to a reciprocal situation at the behest of the taxpayer. E.g., compare Commissioner v. Munter, 331 U.S. 210 (1947) with Commissioner v. Phipps, 336 U.S. 410 (1949).

"A taxpayer is free to adopt such organization for his affairs as he may choose and having elected ... he must accept the tax disadvantages.

"On the other hand the Government may not be required to acquiesce in the taxpayer's election of that form for doing business which is most advantageous to him." Higgins $y$. Smith, 308 U.S. 473,477 (1940).

"There is another reason why generalizations ... have a special peril in connection with tax avoidance. A great many tax avoidance cases have in them no legal message - their difficulty is factual. ...

"There is need to recognize this characteristic of many tax avoidance cases so that we avoid the mistake of drawing from any particular case an overload of meaning." Paul, Restatement of the Law of Tax Avoidance, Studies in Federal TAXation 91-2 (193i).

38. Before the Cumberland and Kimbell-Diamond decisions the inconsistent treatment and concomitant loss of revenue were not such serious problems. Distaste for litigation and doubt that the tax could be successfully avoided probably deterred many corporations from attempting alternatives to the direct sale technique. But now that the paths to successful avoidance are somewhat more clearly delineated, it may be expected that more transferors will seek to avoid the corporate tax.

39. In addition to the major inequity of two taxes imposed on the direct sale and only one tax on the other transfers, there exists a minor inconsistency. Although the liquidation-asset sale and stock sale-liquidation methods both result in one tax, Purchaser corporation will end up with a different asset basis depending on which technique it employs. Under the liquidation-asset sale device the basis is the amount paid for the assets. But use of the stock sale-liquidation technique requires use of the low basis which the assets had in Seller's hands, provided the transaction comes within the terms of section $112(\mathrm{~b})(6)$, see note 20 supra. It seems irrational to impose this low basis just because a different method has been used to arrive at the same result. The courts might eliminate this discrepancy by applying the Kimbell-Diamond rationale and holding the stock sale-liquidation transaction in effect an asset purchase.

40. Revenue Revision Act of 1948, H.R. 6712, 80th Cong., 2d Sess. $\$ 129$ (1948), 94 CoNG. REc. 9191 (1948). Section 129 of the bill provided for non-recognition of corporate 
afford uniformity. However, it is inconsistent with one of the fundamental principles of the Code-that a corporation should be treated as a distinct entity. ${ }^{41}$ Perhaps a better system would be to tax the appreciation of assets in Seller corporation's hands, no matter which type of transfer is used. ${ }^{42}$ A tax of this sort could be effected by relatively simple legislative changes.

The most practical approach ${ }^{43}$ would be Congressional enactment reversing the rule of section 29.22 (a)-20 which makes non-taxable the gain

gain when assets were sold by a corporation, provided that prior to the sale a written plan of complete liquidation was formally adopted and that the plan was carried out within twelve months. Although the bill passed the House, 94 CoNG. REc. 9217 (1948), it was never voted upon by the Senate.

41. This doctrine is implicit in many sections of the Code. Its primary manifestation is in the separate corporate income tax. It is further reflected in the fact that shareholders need not report income as their corporation earns it but only as it is distributed by the corporation to them. See note 42 infra.

42. The pros and cons of recognizing the corporate entity in federal taxation have been extensively debated. For an excellent survey of some of the considerations fundamental to the establishment of a policy, see Goode, The Postwar Corporation Tax Structure (Treas. Dep't, Tax Research Div., 1946).

Firm Congressional policy seems to be to regard corporations as distinct entities for income tax purposes. Many experts have criticized this "double taxation" of dividends. See, e.g., Special Tax Study Committee Report to the Ways and Means Committee, House of Representatives, Majority Report p. 14 (Nov. 4, 1947). But others have held it an eminently sound procedure. "The manifold advantages of limited liability, perpetual existence, convenient exchange of ownership, not to mention the lucrative tax advantages of incorporation, fully justify the corporate tax. . . ." Id., Minority Report at 41-2. Among the possible tax advantages to shareholders of incorporation is that of not having to take money as it is earned. The shareholders are able to cause the corporation to declare a dividend whenever it is taxwise most suitable to them.

Even if the desirability of taxing earnings twice is conceded, however, it may be argued that a "double tax" on asset appreciation when the corporation is about to liquidate is not justified. For the shareholders will not continue to have the corporate advantages. But contrariwise it may be asserted that since the shareholders have had the benefits of incorporation during the corporate existence they should not be allowed to escape a tax simply because they are now giving them up. For the assets appreciated under the corporate mantle, and the tax is assessed at the time of dissolution simply because it is a convenient time to determine the assets' value. Their value must be determined anyway to ascertain the tax on the shareholders.

43. An alternative legislative change has been suggested. "Thus it could be provided that a tax would be payable by the corporation upon any sale of assets made by the shareholders within one year (or other appropriate period) of their distribution in liquidation, or upon the liquidation of a corporation within one year of the purchase of an arbitrarily defined percentage of the stock." 63 HARv. L. REv. 484, 493-4 (1950). This course seems unnecessarily complicated. And the tax could probably be circumvented. When shareholders receive appreciated assets in liquidation, they hold them at the higher basis. If they immediately transferred them to a newly-organized corporation it would also hold them at the higher basis. If the corporation then sold the assets, it would realize no gain since its basis would be equal to selling price. And the sale would not be taxed to the shareholders tecause it was consummated by the new corporation. Nor would shareholders have a gain when proceeds of sale were distributed to them as a liquidating distribution of the newlyorganized corporation, since their basis for stock would be equal to the basis of the assets they gave in exchange for it. 
realized by a corporation on assets distributed in kind in partial or complete liquidation. ${ }^{44}$ Thus capital appreciation would be taxed either when the corporation sells its assets in the direct sale transaction or when it distributes them in liquidation in the liquidation-asset sale procedure. ${ }^{45}$

What effect this would have on the stock sale-liquidation device depends on how other courts treat the Kimbell-Diamond decision. If the Tax Court's reasoning is not followed and the stock purchase and subsequent liquidation are regarded as two separate transactions, modification of section 29.22(a)-20 will extend uniform treatment to this mode of transfer. ${ }^{46}$ The second tax will be payable when Purchaser corporation liquidates its newly-acquired subsidiary. ${ }^{47}$

44. Generally, revision of the Regulations is within the power of the Commissioner. INT. REv. CODE $\$ 3791$. But the venerability of the language of section 29.22(a)-20 seems to preclude anything but a legislative change. See note 11 supra.

Moreover, many commentators assert that "[ $t]$ he present Treasury Regulation, which provides that no gain is realized by a corporation upon assets liquidated in kind, is consistent with the reasoning of the Supreme Court expressed in a decision dealing with dividend distributions in kind. In that case, General Utilities \& Operating Co. v. Helvering [296 U.S. 200 (1935)], the corporation did not realize any gain upon distribution of the dividend in kind because the corporation was not selling its assets nor exchanging them as payment for a corporate debt." 14 U. of CHI. L. REv. 647, 655-6 (1947). Some writers, however, maintain that the General Utilities case never specifically decided this issue. See Raum, Dividends in Kind: Their Tax Aspects, 63 Harv. L. Rev. 593, 599 (1950); Paul, Ascertainment of "Earnings or Profits" for the Purpose of Determining Taxability of Corporate Distributions, 51 HARv. L. Rev. 40, 57(1937).

45. INT. REv. CODE $\S 111$ (a) provides: "The gain from the sale or other disposition of property shall be the excess of the amount realized therefrom over the adjusted basis. . . ." The "amount realized" is the money received plus the fair market value of the property received. INT. REv. CODE $\$ 111$ (b). In the liquidation-asset sale type of transaction, the corporation, in exchange for the assets distributed in liquidation, receives stock which has a fair market value commensurate with the assets' fair market value. The gain to the corporation is the difference between the market value of the stock received and the adjusted basis of the assets. With section 29.22 (a)-20 no longer applicable, the corporation will be taxed on this gain.

46. Absolutely uniform treatment will still not prevail. Under all three methods the corporation will be taxed on the difference between adjusted basis and market value of assets. But the tax on the shareholders may not be the same in the three situations. In the liquidation-asset sale and stock sale-liquidation transactions this will always be a capital gains tax. However, the tax on the shareholders when they receive the proceeds of the sale in the direct sale transfer may be either a regular income tax or a capital gains tax. See notes 9 and 10 supra. Nevertheless, considerably more uniformity will be provided than exists under present law.

47. In most cases sections $112(b)(6)$ and $113(a)(15)$ will apply to the liquidation. But since the liquidated corporation will now pay a tax on appreciation, it will probably be held that the liquidated corporation's basis has increased to appreciated value of the assets. For it is a general rule of the Code that when a transaction is subject to an income tax there is a basis change. Purchaser corporation would thus take the assets at this higher basis.

The burden of the tax paid by the liquidated corporation will fall on its new shareholder-Purchaser corporation. But Purchaser corporation will probably take this into account when it fixes the amount it is willing to pay for the stock. Thus the price the corporation's original shareholders receive will be proportionately reduced. 
But there is the possibility that the Tax Court's rationale will be followed and the transaction regarded as a purchase of assets. ${ }^{48}$ In this event the Commissioner will probably argue that if there has been a purchase of assets there must have been a sale of assets. ${ }^{49}$ If he is successful the transfer will be treated like a direct sale and asset appreciation will be taxed to Seller corporation. ${ }^{50}$ More probably, however, the courts will find a purchase of assets but a sale only of stock. ${ }^{51}$ In such case the liquidation will be completely ignored. If the courts do this, the decision would have to be narrowed by legislative enactment to prevent tax avoidance. ${ }^{52}$

Whatever techniques it chooses, Congress should take immediate steps to equalize tax results of the three methods of transfer. The incidence of taxation should not depend on the availability of competent counsel.

Of course this second tax may be indefinitely avoided if Purchaser corporation, instead of liquidating Seller corporation, continues to operate it as a subsidiary. But the newlyacquired subsidiary must continue to use the same low basis of the assets for depreciation purposes. And when any liquidation ultimately does take place there will be a tax on the difference between the market value of the assets at that time and their adjusted basis.

48. It seems even more likely that the courts will conclude that assets themselves were bought if, as frequently happens, what Purchaser acquired was a "semi-useless" corporation, "milked" of all assets but the ones Purchaser desired to buy. See, e.g., Prairie Oil \& Gas Co. v. Motter, 66 F.2d 309 (10th Cir. 1933).

49. The Commissioner has proffered this rationale in a number of recent cases. But the Tax Court has been unwilling to accept it. See, e.g., Dallas Downtown Development Co., 12 T.C. 114 (1949); The Steubenville Bridge Co., 11 T.C. 789 (1948). The problem is discussed in Mintz, Seven Suggestions for Avoiding Double Taxation When Stock Sale May Be Transfer of Assets, $88 \mathrm{~J}$. Accountancy 63 (1949).

50. But of course at this stage of the transaction Seller corporation has been liquidated. The question will then arise as to who is liable for the corporate tax. Seller corporation's original shareholders will probably be required to pay, since they are the real parties in interest and the transferees of the proceeds of the constructive sale by Seller corporation. INT. REv. CoDE \$ 311; U.S. Treas. Reg. 111, \$ 29.311-1 (1945). But Purchaser corporation may be held liable as the successor of Seller corporation. In the latter event Purchaser could anticipate the second tax by a corresponding reduction in the price it pays for the stock.

The general question of transferee liability for taxes on intercorporate asset transfers is discussed in Magill, supra note 1, at 717-20.

51. This seems a fair inference from the Commissioner's lack of success in the Dallas and Steubenville cases, supra note 49 . Moreover the Commissioner has recently acquiesced in these decisions. 1950 INT. REv. Burl. No. 9 at 1, 2(1950).

52. Such legislation might take the form of a provision arbitrarily taxing any liquidation of a corporation within a given period of time after the purchase of a given percentage of its stock. Cf. note 43 supra. 